\title{
Skrining Sistematik terhadap Hiperkolesterolemia Familial pada Anak Berdasarkan Kriteria MedPed, Simon Broome Register Register dan Dutch Lipid Elinic
}

\author{
Titis Prawitasari, Sudigdo Sastroasmoro, Damayanti R. Sjarif \\ Departemen Ilmu Kesehatan Anak Fakultas Kedokteran Universitas Indonesia RS Dr. Cipto Mangunkusumo< \\ Jakarta
}

\begin{abstract}
Latar belakang. Hiperkolesterolemia familial (HF) merupakan kelainan genetik tersering penyebab terjadinya penyakit jantung koroner/aterosklerosis. Penyakit tersebut seringkali terlambat diketahui, padahal jika dapat diketahui sejak usia muda terjadinya penyakit jantung koroner dan kematian dapat dicegah. Terdapat berbagai macam kriteria untuk dapat mendeteksi dini HF pada orang dewasa, yaitu MedPed, Simon Broome Register dan Ducth Lipid Clinic.

Tujuan. Mendeteksi secara dini HF pada anak dengan riwayat orangtua mengalami penyakit jantung koroner dini dan hiperkolesterolemia berdasarkan kriteria MedPed, Simon Broome Register dan Ducth Lipid Clinic.

Metode. Studi potong lintang dari anak dengan riwayat orangtua mengalami PJK dini dan hiperkolesterolemia. Terhadap anak dan orangtua dilakukan pemeriksaan fisis dan laboratorium profil lipid (kolesterol total, LDL, HDL, trigliserida dan Apo B) kemudian digolongkan ke dalam 3 kriteria diagnosis berdasarkan MedPed, Simon Broome Register dan Dutch Lipid Clinic. Dilakukan juga pemeriksaan untuk menyingkirkan kemungkinan peningkatan kolesterol akibat penyakit lainnya.

Hasil. Terdapat 28 subyek dan 20 kasus indeks dari 20 keluarga. Rerata usia anak adalah 11,6 \pm 4,75 tahun, dengan rerata usia kasus indeks 47,8 $\pm 5,50$ tahun. Rerata usia saat kasus indeks mengalami serangan jantung pertama kali adalah 45,3 5,65 tahun. Berdasarkan data yang ada dilakukan penggolongan sesuai kriteria MedPed, Simon Broome Register dan Dutch Lipid Clinic. Didapatkan 15\% (3/20) anak yang mungkin menderita HF berdasarkan kriteria MedPed, jika menggunakan kriteria Simon Broome Register didapatkan sekitar 10\% (2/20) sedangkan dengan kriteria Dutch Lipid Clinic didapatkan 50\% (10/20) anak yang sangat mungkin (probable) mengalami HF dan 30\% (6/20) lainnya mungkin (possible) mengalami HF. Pada penelitian ini memang tidak dilakukan pemeriksaan genetik.

Kesimpulan. Kriteria Dutch Lipid Clinic dapat lebih banyak mendeteksi kemungkinan anak yang mengalami HF berdasarkan riwayat orangtua mengalami penyakit jantung koroner dini dan hiperkolesterolemia dibandingkan kriteria lainnya. Sari Pediatri 2011;13(2):152-8.
\end{abstract}

Kata kunci: hiperkolesterolemia, familial, penyakit jantung koroner dini, skrining

Alamat korespondensi:

Dr. Titis Prawitasari, Sp.A. Departemen Ilmu Kesehatan Anak FKUI - RSCM. Jl. Salemba no.6, Jakarta 10430. Tel.: 021-3910096. E-mail: tprawitasari@yahoo.com

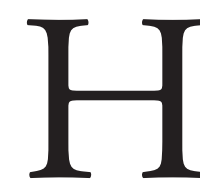

iperkolesterolemia familial (HF) merupakan salah satu penyebab tersering dari kelainan gen pengatur homeostatis lemak tubuh. ${ }^{1}$ Kelainan 
hiperkolesterolemia familial terjadi karena adanya mutasi pada gen reseptor LDL (R-LDL) sehingga terjadi perubahan struktur maupun fungsi dari reseptor yang mengikat low density lipoprotein cholesterol (kolesterol LDL) plasma. Hal ini mengakibatkan tingginya kadar kolesterol LDL yang dapat memberikan berbagai spektrum klinis, dari penumpukan kolesterol pada kulit dan jaringan ikat hingga aterosklerosis pada pembuluh darah koroner yang akan menyebabkan kematian. $^{2}$

Hiperkolesterolemia familial diturunkan secara autosomal dominan. Berdasarkan banyaknya mutan, dikenal adanya HF homozigot dan HF heterozigot. Diperkirakan angka kejadian HF hereozigot pada populasi ras Kaukasia berkisar 1 diantara 200-1000, dengan rerata 1:500, sedangkan untuk HF homozigot berkisar 1 di antara 1.000 .000 populasi. ${ }^{2,3}$ Manifestasi awal HF umumnya hanya berupa peningkatan kadar kolesterol dalam darah. Manifestasi penyakit jantung koroner pada HF heterozigot umumnya timbul pada dekade keempat, sedangkan pada HF homozigot manifestasi penumpukan kolesterol terjadi lebih dini dan aterosklerosis dapat timbul sejak usia kanak-kanak sehingga kematian akibat penyakit jantung koroner terjadi pada usia lebih muda, biasanya sebelum dekade ketiga. Saat ini, pada umumnya kasus HF diketahui secara kebetulan setelah adanya manifestasi klinis pada pembuluh darah koroner. ${ }^{2}$

Berbagai jenis kriteria klinis, laboratorium, dan analisis DNA ditetapkan untuk memudahkan dalam melakukan diagnosis hiperkoleterolemia familial ini. Tetapi adanya mutasi DNA merupakan baku emas diagnosis. ${ }^{2,4,5}$ Penelitian terhadap HF lebih banyak dilakukan pada ras Kaukasia, sedangkan pada bangsa Asia belum banyak diteliti. Ekspresi genetik antar ras tentu saja dipengaruhi juga oleh berbagai faktor lain diantaranya usia, jenis kelamin, pola diet, gaya hidup serta faktor risiko lainnya. ${ }^{6,7}$ Penelitian ini bertujuan untuk melihat kemungkinan hiperkolesterolemia familial berdasarkan kriteria MedPed, Simon Broome Register dan Dutch Lipid Clinic pada anak dengan orangtua mempunyai riwayat penyakit jantung koroner dini dan hiperkolesterolemia.

\section{Metode}

Penelitian dengan desain potong lintang, dilakukan di Departemen Ilmu Kesehatan anak FKUI RSCM, Pusat
Jantung Terpadu RSCM pada bulan September Desember 2010. Kriteria inklusi pada penelitian adalah anak berusia 2-18 tahun dari orangtua dengan riwayat penyakit jantung koroner dini (sebelum usia 55 tahun untuk laki-laki dan 60 tahun untuk perempuan; kasus indeks) yang berobat di RSCM Jakarta dan terbukti mengalami hiperkolesterolemia serta menyatakan kesediaan untuk ikut serta dalam penelitian ini. Pada anak yang mengalami kelainan hati, ginjal, tiroid atau obat mendapat antilipidemia tidak diikutsertakan dalam penelitian. Data kasus indeks didapat berdasarkan rekam medis yang ada pada Pusat Jantung Terpadu RSCM dan Unit Perawatan Kardiologi Intensif RSCM. Subyek dan atau orangtua subyek yang telah diberi penjelasan mengenai penelitian harus menandatangani surat informed consent yang menyatakan kesediaan untuk berpartisipasi dalam penelitian ini. Selanjutnya dilakukan pencatatan terhadap terhadap subyek dan kasus indeks yang mencakup identitas, riwayat penyakit saat ini dan dahulu, riwayat penyakit dalam keluarga (PJK dan faktor risiko terhadap PJK, seperti hipertensi, diabetes melitus, obesitas, merokok) dan pedigree. Pemeriksaan fisis dilakukan oleh peneliti, untuk mencari manifestasi klinis HF (arkus kornea, xanthoma), juga dilakukan pengukuran antropometri (berat badan, tinggi badan, IMT) dan tekanan darah. Pemeriksaan laboratorium terhadap kolesterol total, trigliserida dan kolesterol HDL dilkukan terhadap anak dan orangtuanya setelah mereka berpuasa selama 12 jam, setelah itu dilakukan penggolongan sesuai dengan kriteria MedPed, Simon Broome Register dan Dutch Lipid Clinic (tertera pada Lampiran).

\section{Hasil}

Berdasarkan rekam medis didapatkan 249 pasien mengalami PJK dini dan hiperkolesterolemia. Dilakukan pemanggilan kasus indeks melalui pengiriman surat, telepon, atau mendatangi alamat langsung. Melalui cara tersebut terjaring 103 keluarga, tetapi 32 di antaranya tidak mempunyai anak $<18$ tahun, 2 keluarga tidak mempunyai anak, 10 keluarga menolak ikut penelitian, 7 keluarga diketahui pindah alamat. Sampai saat ini terdapat 52 keluarga (20\%) yang sesuai dengan kriteria dan menyutujui ikut dalam penelitian. Terdapat 20 keluarga yang ikut dalam penelitian, terdiri dari 20 pasien indeks dan 28 anak berusia 2-18 tahun. 
Titis Prawitasari dkk: Skrining sistematik terhadap hiperkolesterolemia familial pada anak

Tabel 1. Sebaran karakteristik subyek $(\mathrm{n}=28)$

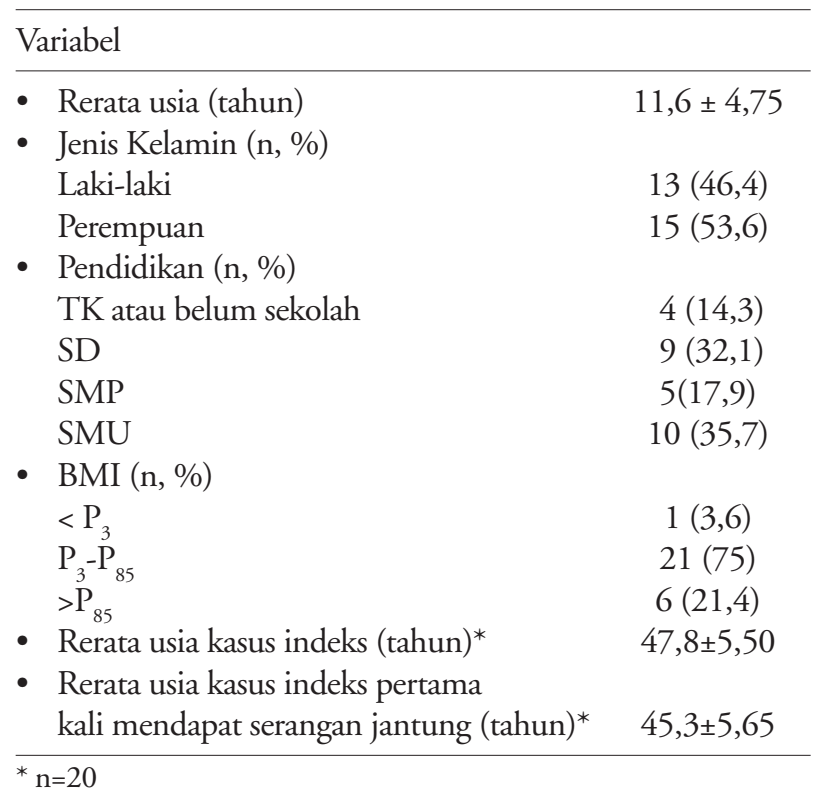

Tabel 2. Sebaran pasien indeks berdasarkan kriteria MedPed, Simon Broome Register, Dutch Lipid Clinic $(\mathrm{n}=20)$

\begin{tabular}{lc}
\hline \multicolumn{1}{c}{ Kriteria } & Jumlah (\%) \\
\hline Kimia darah & \\
$\quad$ MedPed & $3(15)$ \\
Kolesterol total (1 ${ }^{\text {st }}$ degree) & \\
Klinis & \\
$\quad$ Simon Broome Register & \\
$\quad$ Register & \\
$\quad$ Definite & \\
$\quad$ Prbable & \\
Dutch Lipid Clinic & \\
$\quad$ Definite & \\
$\quad$ Probable & \\
$\quad$ Possible & $10(50)$ \\
\end{tabular}

Tabel 3. Perbandingan sensitivitas dan spesifisitas berbagai kriteria ${ }^{10}$

\begin{tabular}{lcc}
\hline Kriteria & Sensitivitas (\%) & Spesifisitas (\%) \\
\hline Kimia darah & & \\
MedPed & & 73,4 \\
$\quad$ Kolesterol total & 63,4 & 69,8 \\
$\quad$ Kolesterol LDL & 70,3 & \\
Klinis & & \\
Simon Broome Register & & 89,4 \\
$\quad$ Definite & 34,1 & 28,6 \\
$\quad$ Probable & 90,4 & \\
Dutch Lipid Clinic & & 87,9 \\
$\quad$ Definite & 41,5 & 64,5 \\
$\quad$ Probable & 66,7 & 5,9 \\
$\quad$ Possible & 99,3 & \\
\hline
\end{tabular}

Pada Tabel 1 tampak pada umumnya 1 kasus indeks mempunyai 1-2 orang anak yang berusia 2-18 tahun. Rerata usia orangtua sebagai kasus indeks sekitar 47,8 5,50 tahun, dengan rerata usia pertama kali mengalami serangan jantung 45,3 $\pm 5,65$ tahun. Hasil yang tidak jauh berbeda didapatkan pada penelitian Andristuti, $\mathrm{dkk}^{8}$ dan data yang dikumpulkan Goldstein, $\mathrm{dkk}^{2}$ yang mendapatkan usia terjadinya PJK pertama kali sekitar 43 tahun pada pria dan 53 tahun pada wanita. Rerata usia anak dari kasus indeks sekitar 11,6 64,75 tahun, dengan usia termuda 2 tahun dan usia tertua 17 tahun. Hanya kurang dari 30\% dari keseluruhan yang termasuk dalam kategori overweight atau obese dan kurang dari $10 \%$ anak yang juga mengalami hipertensi. Hal yang sebaliknya terjadi pada kasus indeks, lebih dari dua pertiga kasus indeks mempunyai IMT di atas 25 .

Empat belas dari 20 kasus indeks (70\%) mempunyai lebih dari 1 faktor risiko tradisional terjadinya PJK, dan 50\% kasus indeks mempunyai kadar kolesterol total maupun LDL yang tinggi atau borderline. 
Dijunpai 3 di antara 20 kasus indeks yang juga mengalami hipertrigliseridemia, artinya 17 kasus sangat mungkin untuk mengalami hiperkolesterolemia yang bukan tipe campuran. Perlu diketahui bahwa semua pemeriksaan dilakukan tanpa menghentikan obatobatan yang biasa diminum, termasuk antilipidemia (biasanya pasien mendapat antilipidemia golongan statin, antihipertensi golongan penghambat $\mathrm{Ca}$ ).

Berdasarkan data pada 20 kasus indeks tersebut, dicoba untuk menggunakan kriteria diagnosis yang biasa dipakai di dunia, yaitu MedPed, Simon Broome Register Register, dan Dutch Lipid Clinic. Ketiga kriteria ini merupakan kriteria diagnosis untuk orang dewasa karena hingga saat ini belum ada yang secara spesifik untuk anak. Kriteria tersebut dapat digunakan pada penelitian ini karena pada penelitian ini juga diambil data riwayat (berdasarkan anamnesis dan pedigree tentang penyakit jantung koroner pada keluarga), dilakukan pemeriksaan kadar kolesterol (anak dan orangtua) serta juga dicari adanya kemungkinan manifestasi klinis tanda penumpukan kolesterol pada organ syarat perhitungan skoring berdasarkan kriteria tersebut. Memang pada penelitian ini belum dilakukan mpemeriksaan genetik sebagai konfirmasi diagnosis dan baku emas dari hiperkolesterolemia familial. Tertera pada Tabel 2, dengan mempergunakan kriteria $\mathrm{MedPed}$ yang hanya memperhitungkan kadar kolesterol darah saja, didapatkan 3/20 (15\%) kasus indeks kemungkinan mengalami menderita HF, sedangkan dengan menggunakan Simon Broome Register didapatkan 2/20 (10\%) kasus indeks mengalami HF. Berdasarkan kriteria Dutch Lipid Clinic yang menggabungkan kriteria klinis dan laboratoris serta adanya mutasi (jika ada) didapatkan 10 dari 20 (50\%) kasus indeks tergolong sebagai kasus yang probable atau sangat mungkin mengalami hiperkolesterolemia familial. Perbedaan jumlah yang terjadi karena kriteria Dutch Lipid Clinic lebih banyak mencantum variabel berdasarkan anamnesis (riwayat) dan kadar penggolongan kolesterol yang lebih bervariasi sehingga tampak lebih akomodatif terhadap data yang ada.

\section{Pembahasan}

Saat ini terdapat tiga macam kriteria diagnosis HF untuk orang dewasa yang telah dikembangkan di dunia, yaitu US MedPed Program (Amerika Serikat), Simon Broome Register Group (Inggris), dan Dutch Lipid Clinic
Network (Belanda). Kriteria MedPed menggunakan nilai ambang batas kadar kolesterol total berdasarkan usia dan riwayat keluarga dari individu. Kriteria MedPed membedakan nilai ambang batas kolesterol total untuk masing-masing tingkatan derajat keluarga (first-, second-, or third-degree relatives) $)^{1,6,7}$ Berbeda dengan kriteria dari Simon Broome Register dan Dutch Lipid Clinic Network yang tidak saja memperhitungkan kadar kolesterol tetapi juga memasukkan karakteristik klinis dan diagnosis molekular serta riwayat keluarga dalam menentukan diagnosis pasti dari HF. 9,10

Pada Simon Broome Register, seseorang dikatakan HF 'definite' (pasti) jika individu tersebut mengalami peningkatan kadar kolesterol (di atas nilai ambang batas sesuai umur) dan mempunyai manifestasi xantomata tendinous atau adanya bukti mutasi pada gen reseptor LDL atau gen Apo B-100. Dikatakan HF 'probable' (sangat mungkin) jika individu tersebut mengalami peningkatan kadar kolesterol dan mempunyai riwayat keluarga mengalami hiperkolesterolemia atau penyakit jantung (Tabel 2). ${ }^{9,10}$

Sedikit berbeda dengan kriteria dari the Simon Broome Register, kriteria dari Dutch Lipid Clinic Network, menambah satu klasifikasi lagi selain 'definite' dan 'probable', yaitu dengan kategori 'possible. Hal itu diperhitungkan berdasarkan sistim skoring (tertera pada Lampiran). Jika Simon Broome Register menilai kepastian diagnosis (definite diagnosis) harus berdasarkan bukti diagnosis molekular, maka kriteria Dutch Lipid Clinic Network juga menambahkan paling tidak satu kriteria lainnya (selain pembuktian secara molekular) untuk menyatakan diagnosis pasti HF.9,10

Berbagai kriteria diagnosis tersebut dapat digunakan sesuai dengan kebutuhan yang ada. Penggunaan kriteria diagnosis ini tidak selalu menghasilkan sensitivitas dan spesifisitas yang sama jika digunakan pada populasi yang berbeda. ${ }^{9-12}$

Hal ini disebabkan adanya pengaruh nilai ambang batas kadar kolesterol pada populasi tersebut, juga pengaruh faktor usia dan jenis kelamin. ${ }^{2,6}$ Sensitivitas dan spesifisitas akan meningkat jika digunakan nilai ambang batasnya disesuaikan berdasarkan usia, jenis kelamin serta spesifik untuk populasi tersebut. ${ }^{2,6,13}$ Pada Tabel 3 tampak perbandingan berbagai kriteria berdasarkan sensitivitas dan spesifisitas. Terlihat bahwa baik kriteria berdasarkan Simon Broome Register (probable) dan Dutch lipid Clinic (possible) mempunyai sensitivitas di atas $90 \%$ yang artinya sangat baik untuk menyingkirkan ada kelainan HF ini. 
Titis Prawitasari dkk: Skrining sistematik terhadap hiperkolesterolemia familial pada anak

Selain itu pula adanya kriteria riwayat keluarga mengalami PJK dini yang digunakan oleh Simon Broome Register dan Dutch Lipid Clinic Network, sangat dipengaruhi oleh prevalens dari penyakit tersebut di populasi. ${ }^{6,13}$ Sebagai contoh, spesifisitas akan menurun jika digunakan pada daerah dengan angka kejadian PJK yang tinggi, seperti di Eropa dan Amerika Serikat. Hal yang sebaliknya mungkin terjadi jika diterapkan pada negara-negara Asia-Pasifik. Kelemahan lainnya yang mungkin terjadi jika kriteria klinis (xantomata, PJK) diterapkan adalah bahwa manifestasi klinis tersebut seringkali timbul pada usia dewasa, sehingga sangat sulit untuk menemukannya pada pasien yang masih berusia muda atau pada anggota keluarga yang belum dewasa. ${ }^{6,13,14}$ Oleh karenanya diperlukan penelitian lebih lanjut agar dapat memfasilitasi berbagai kelemahan pada penelitian tersebut.

\section{Kesimpulan}

Kami mendapatkan kriteria diagnosis berdasarkan Dutch Lipid Clinic dapat medeteksi kemungkinan (probable dan possible) HF pada populasi yang telah terseleksi dengan sistematik, yaitu anak dengan riwayat orangtua mengalami penyakit jantung koroner dini dan hiperkolesterolemia.

\section{Daftar pustaka}

1. World Health Organization. Familial Hypercholesterolaemia (FH): Report of a second WHO consultation. Geneva: World Health Organization, 1999.

2. Goldstein JL, Hobbs HH, Brown MS. Familial hypercholesterolemia. In: Scriver CR, Baudet AL, Sly WS, Valle D, eds. The Metabolic and Molecular Bases of Inherited Disease. New York, New York: McGraw-Hill; 2001:2863-913.

3. Hobbs HH, Brown MS, Goldstein JL. Molecular genetics of the LDL receptor gene in familial hypercholesterolemia. Hum Mutat. 1992;1:445-66.

4. Marks D, Wonderling D, Thorogood M, Lambert H, Humphries SE, Neil HAW. Screening for hypercholesterolaemia versus case finding for familial hypercholesterolaemia: a systematic review and cost effectiveness analysis. Health Technol Assess. 2000;4:1123.

5. Austin MA, Hutter CM, Zimmern RL, Humphries SE. Genetic causes of monogenic heterozygous familial hypercholesterolemia: a HuGE prevalence review. Am J Epidemiol. 2004;160:407-20.

6. Pimstone SN, Sun XM, du Souich C, Frohlich JJ, Hayden MR, Soutar AK. Phenotypic variation in heterozygous familial hypercholesterolemia: A comparison Chinese patients with the same or similar mutations in the LDL receptor gene in China or Canada. Arterioscler Thromb. 1998;18:309.

7. Sun XM, Patel DD, Webb JC, Knight BL, Fan LM, Cai HJ, Soutar AK. Familial hypercholesterolemia in China. Arterioscler Thromb. 1994;14:85.

8. Andriastuti M, Sastroasmoro S, Firmansyah A. Faktor risiko penyakit jantung koroner pada anak dan dewsa muda dengan riwayat orangtua menderita penyakit jantung koroner (tesis). Jakarta: Universitas Indonesia; 2002.

9. Marks D, Wonderling D, Thorogood M, Lambert $\mathrm{H}$, Humphries SE, Neil HAW. Cost effectiveness analysis of different approaches of screening for familial hypercholesterolaemia. BMJ. 2002;324:1303-8.

10. Reis EC, Kip KE, Marroquin OC, Kiesau M, Hipps L, Peters RE, Reis SE. Screening children to identify families at increased risk for cardiovascular Pediatrics. 2006;118;e1789-97.

11. Wald DS, Bestwick JP, Wald NJ. Child-parent screening for familial hypercholesterolaemia: screening strategy based on a meta-analysis BMJ. 2007;335:599-606.

12. Herman K, Van Heyningen C, Wile D. Cascade screening for familial hypercholesterolaemia and its effectiveness in the prevention of vascular disease. $\mathrm{Br} \mathrm{J}$ Diabetes Vasc Dis. 2009;9:171-4.

13. Kwiterovich PO. Cut Points for lipids and lipoproteins in children and adolescents: should they be reassessed? Clin Chemistry. 2008;54:1113-5.

14. Herman K, Van Heyningen C, Wile D. Cascade screening for familial hypercholesterolaemia and its effectiveness in the prevention of vascular disease. British Journal of Diabetes \& Vascular Disease 2009; 9; 171-4. 
Titis Prawitasari dkk: Skrining sistematik terhadap hiperkolesterolemia familial pada anak

\section{Lampiran}

Tabel 1. Kriteria diagnosis hiperkolesterolemia familial the US MedPed Program ${ }^{9}$

\begin{tabular}{|c|c|c|c|c|}
\hline \multirow[t]{2}{*}{ Umur (tahun) } & \multicolumn{4}{|c|}{ Kolesterol total cutpoints ( $\mathrm{mmol} /$ liter) } \\
\hline & $\begin{array}{c}\text { Keluarga derajat } \\
\text { pertama dengan HF }\end{array}$ & $\begin{array}{c}\text { Keluarga derajat } \\
\text { kedua dengan HF }\end{array}$ & $\begin{array}{c}\text { Keluarga derajat ketiga } \\
\text { dengan HF }\end{array}$ & Populasi umum \\
\hline$<20$ & 220 & 228 & 240 & 270 \\
\hline $20-29$ & 240 & 251 & 259 & 290 \\
\hline $30-39$ & 270 & 278 & $290 \mathrm{~L}$ & 340 \\
\hline$\geq 40$ & 290 & 301 & 309 & 359 \\
\hline
\end{tabular}

Tabel 2. Kriteria diagnosis berdasarkan Simon Broome Register ${ }^{9}$

\begin{tabular}{ll}
\hline Kriteria & Deskripsi \\
\hline A & Kadar kolesterol total di atas $7.5 \mathrm{mmol} / \mathrm{L}(290 \mathrm{mg} / \mathrm{dL})$ untuk dewasa atau di atas $6.7 \mathrm{mmol} / \mathrm{L}(259$ \\
& $\mathrm{mg} / \mathrm{dL})$ untuk anak < 16 tahun, atau \\
& Kadar kolesterol LDL di atas $4.9 \mathrm{mmol} / \mathrm{L}(189 \mathrm{mg} / \mathrm{dL})$ untuk dewasa atau di atas $4.0 \mathrm{mmol} / \mathrm{L}(154$ \\
$\mathrm{mg} / \mathrm{dL})$ untuk anak \\
Xantomata Tendinous pada pasien atau keluarga derajat pertama \\
C & Adanya mutasi DNA pada gen reseptor LDL atau APO-B \\
D & Riwayat keluarga mengalami infark miokardium sebelum usia 50 tahun pada keluarga derajat kedua \\
& atau sebelum 60 tahun pada keluarga derajat pertama \\
E & Adanya riwayat keluarga derajat pertama atau kedua mengalami peningkatan kadar kolesterol total \\
HF "definite" & di atas $7.5 \mathrm{mmol} / \mathrm{L}(290 \mathrm{mg} / \mathrm{dL})$ \\
HF "probable" & Jika memenuhi kriteria A dan B, atau C \\
\hline
\end{tabular}


Tabel 3. Kriteria diagnosis berdasarkan Dutch Lipid Clinic Network ${ }^{7}$

\begin{tabular}{lc}
\hline Kriteria & Nilai \\
\hline Riwayat Keluarga & \\
Derajat pertama mengalami PJK dini atau penyakit vaskular dini (laki-laki $<55$ tahun, perempuan $<60$, atau & 1 \\
Derajat pertama mempunyai kadar kolesterol LDL di atas persentil ke-95 & \\
Derajat pertama mempunyai xantomata tendinous dan/atau arkus kornealis, atau & 2 \\
Anak berusia $<18$ tahun dengan kadar kolsterol LDL di atas persentil ke-95 & \\
Riwayat penyakit & 2 \\
Pasien dengan PJK dini (laki-laki <55 tahun, perempuan <60), atau & 1 \\
Pasien dengan penyakit stroke atau pembuluh darah perifer dini laki-laki <55 tahun, perempuan <60) & \\
Pemeriksaan fisik & 6 \\
$\quad$ Xantomata tendinous & 4 \\
Arkus kornealis sebelum usia 45 tahun & \\
Kadar kolesterol (mmol/L) & 8 \\
$\quad$ LDL $\geq 8,5(328 \mathrm{mg} / \mathrm{dL})$ & 5 \\
LDL 6,5-8,4 $(251-325 \mathrm{mg} / \mathrm{dL})$ & 3 \\
LDL 5,0-6,4 $(193-247 \mathrm{mg} / \mathrm{dL}$ & 1 \\
LDL 4,0-4,9 $(170-189 \mathrm{mg} / \mathrm{dL}$ & \\
Analisis DNA & 8 \\
Mutasi gen reseptor LDL & \\
\hline
\end{tabular}

HF "definite" jika nilai > 8

HF "probable" jika nilai 6-8

HF "possible" jika nilai 3-5 